\title{
RESISTIN ACTIVITY IN MICE AND HUMANS AFFECTING OBESITY, INSULIN RESISTANCE AND T2DM: BLOCKING RESISTIN ACTION BY RESISTIN ANTAGONIST
}

\section{Arieh Gertler}

The Hebrew University of Jerusalem, Institute of Biochemistry, Food Science and Nutrition, Rehovot, Israel

\begin{abstract}
Resistin, that was originally discovered in 2001 is named for its capacity to resist insulin action shown mainly in mice. However, there is a controversial history regarding its role in the pathogenesis of insulin resistance and type 2 diabetes mellitus (T2DM) in humans as most of the research was based on association between resistin blood levels and T2DM or other pathologies and so far the pharmacological effect of recombinant resistin has not been tested in humans or even in primates. Resistin is a $12 \mathrm{kD}$ cysteine-rich small protein acting as covalent dimer. Although human and mouse resistin genes and protein sequences share only approximately $60 \%$ homology, which is less than most hormones conserved across species, the genes are syntenic, with the mouse gene encoding resistin being located at a similar distance from the insulin receptor gene. Unlike mouse resistin which is mainly expressed in adipocytes, human resistin is synthesized predominantly in monocytes and macrophages, especially in the visceral adipose tissue. Resistin's effects are mediated via paracrine and endocrine mechanisms of action through a receptor on the surface of target cells that remains controversial. Others and our study has shown that resistin interacts with the Toll-like receptor 4 (TLR4), however other putative receptors such as an isoform of decorin, mouse receptor tyrosine kinase-like orphan receptor 1 (ROR1) and adenylyl cyclase-associated protein 1 (CAP1) have been also proposed. Downstream targets of resistin provide indirect evidence for its function in intracellular pathways, involving impairment of insulin signaling, response to inflammation and proliferation. Despite the lack of in vivo data concerning the resistin receptor and signaling in primates or humans, there is a need to explore the inflammatory, metabolic and oncogenic effects of resistin on human diseases. To address this challenge we have recently developed resistin mutant (C6A), acting as resistin antagonist which in several in vitro bioassays inhibited resistin action and in mice fed high fat diet (HFD) reduced weight, visceral fat, restored insulin sensitivity and attenuated HFD-induced neuroinflamation.
\end{abstract}

Adipobiology 2014; 6: 5-14

Key words: resistin, resistin antagonists, type 2 diabetes mellitus, metabolic syndrome, insulin resistance, TLR4. 


\section{Introduction}

World Health Organization (WHO) has estimated that more than 347 million people worldwide are affected by diabetes and more specifically type 2 diabetes mellitus (T2DM). In addition WHO has also estimated that deaths due to diabetes will increase by two thirds between 2008 and 2030. Despite the enormous progress made to overcome this pathology, its progression worldwide is in permanent augmentation. Insulin resistance is one of the early features of T2DM, thus, the understanding of the mechanisms involved in the onset of insulin resistance is crucial for an early intervention circumventing then the establishment of T2DM. Insulin resistance is associated to several metabolic diseases and obesity (1). Obesity is now considered as a global epidemic affecting both adults and children, and is associated with significant morbidity and mortality rate and is caused by combination of genetic and environmental factors, including increased caloric intake, sedentary lifestyle and unhealthy eating habits. The prevalence of obesity among children, adolescents and adults has been dramatically increased during the last several decades. Worldwide, close to two billion adults are overweight and over 500 million are obese. According to several epidemiological studies, excessive body weight gain and obesity constitute a serious risk factor for insulin resistance and type 2 diabetes. It is also noteworthy that epidemiological studies reported that neurodegenerative diseases risk such as Alzheimer's disease (AD) is significantly increased 50\%-100\% in diabetic cases (2-4). More importantly, insulin resistance is now considered as an important etiological factor for $\mathrm{AD}$ because it is associated with reduced insulin-induced activation of insulin receptor and subsequent signaling pathways. Thus, the brain insulin resistance appears to be a common feature of $\mathrm{AD}$ constituting most likely an early event and marker of the disease. In addition, insulin resistance and T2DM are associated with inflammation and neuroinflammation that further worsen insulin responsiveness. Therefore, developing new therapeutic tools to fight insulin resistance is of high priority due to its dramatic consequences worldwide.

\section{Resistin and insulin resistance}

Insulin resistance is considered as a common hallmark of many metabolic disorders such as T2DM, obesity, dyslipidemias, inflammation, and cardiovascular diseases (1, 5-7). A tremendous number of publications have treated this issue in different tissues and cellular models. One of the puzzling issues concerns the potential link between obesity, inflammation and insulin resistance. Despite the very rich literature concerning insulin resistance, the molecular and cellular mechanisms linking obesity and inflam- mation to insulin resistance are not fully understood. More especially, how excessive body weight gain progressively promotes insulin resistance is a matter of controversy. Accumulating evidence however suggest that the alteration of whole body insulin responsiveness is initiated in the brain and more precisely in the hypothalamic nuclei, as hypothalamus is the main brain location controlling energy homeostasis by the integration of hormonal and metabolic signals responding to the energy body requirements. These signals mainly originate from adipose tissue (adipokines) and pancreatic $\beta$ cells (insulin). Leptin, adiponectin and resistin are the major adipokines implicated in the regulatory loop involving adipose tissue and the hypothalamus to modulate energy homeostasis. These adipokines are also strong modulators of insulin responsiveness and inflammation at both central and peripheral levels. Among these adipokines, resistin is described as a potential factor in obesity-mediated insulin resistance, T2DM, inflammation $(6,7)$. We have recently reported that chronic ICV resistin infusion deeply impairs insulin responsiveness and signaling in the hypothalamus and peripheral tissues (adipose tissue, liver, muscle) in rats. Additionally, central resistin activates the serine kinases Jun $\mathrm{NH}(2)$-terminal kinase (JNK) and p38 mitogen-activated protein kinase (p38 MAPK), enhances serine phosphorylation of insulin receptor substrate-1, and increases the expression of the pro-inflammatory cytokine interleukin-6 (IL-6) in the hypothalamus and key peripheral insulin-sensitive tissues (8). More importantly, we also reported the direct binding of resistin to Toll-like receptor 4 (TLR4) in the hypothalamus and showed that this binding activates proinflammatory pathways (8). Interestingly, resistin is able to induce the phosphorylation of Akt in neuronal cells in vivo (following ICV infusion) or in cell culture following short-term stimulation (10 to 20 minutes). In the same time, infusing resistin ICV during 14 days led to complete alteration of insulin-dependent Akt phosphorylation. This is explained by the deep alteration of insulin signaling as evidenced by the down-regulation of insulin receptor, the increase of serine phosphorylation of IRS1/IRS-2 and the induction of proinflammatory factors that are also involved in the onset of insulin resistance (Fig. 1). Furthermore, ICV infusion of resistin led to the down regulation of insulin receptor in liver, muscle and other tissues without significant changes in circulating resistin and this is explained by the vagal connexion linking the hypothalamus to the periphery. In term of signaling, Akt is down-stream of resistin/TLR4 signaling and also downstream of insulin receptor/IRS signaling with probably different kinetics of action and also with different targets. Accordingly we hypothesized that resistin/TLR4 Akt pathway will target mainly gene expression whereas for insulin it will mainly target meta- 


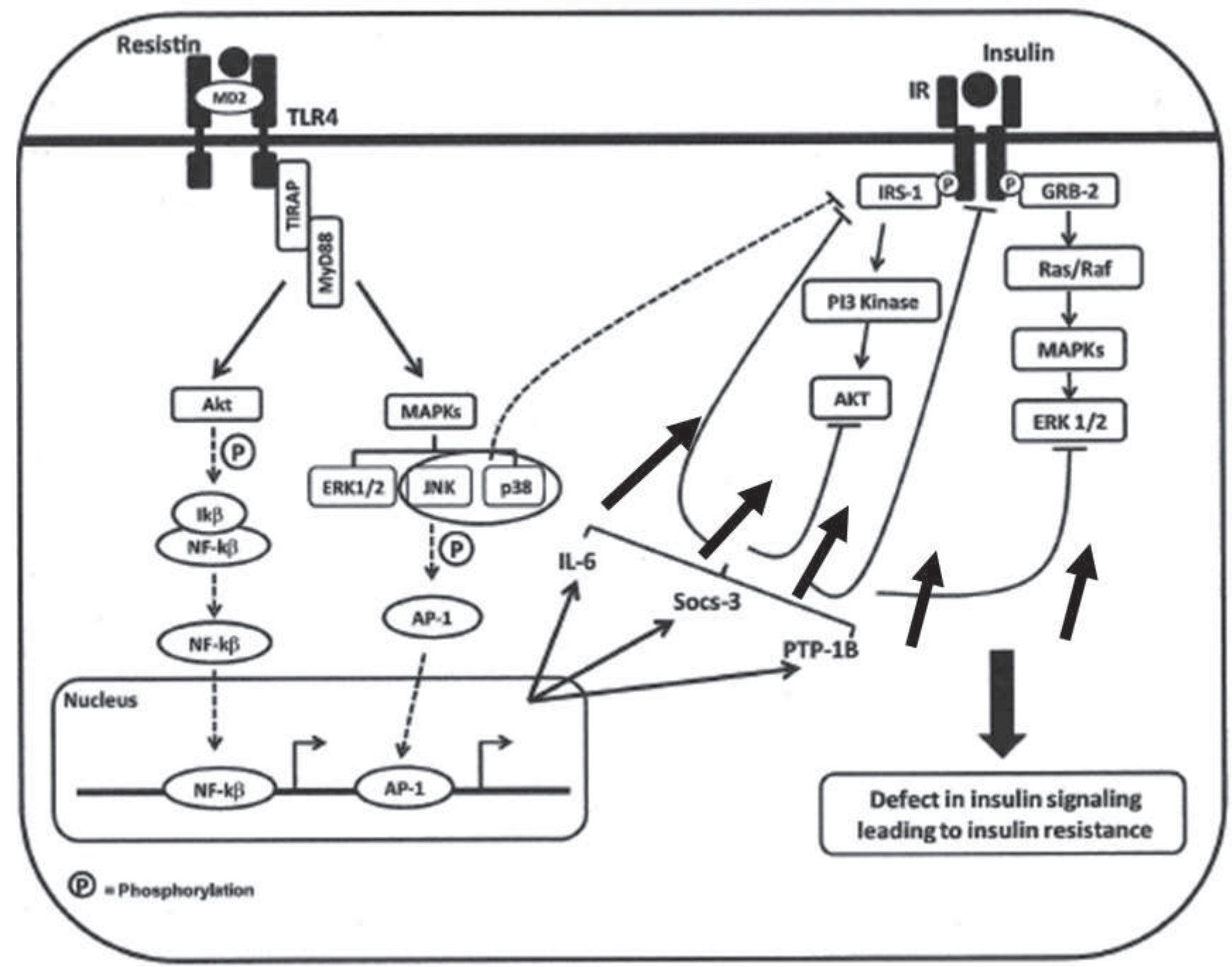

Figure 1. Schematic representation of resistin signaling that leads to inhibition of insulin signaling shown by 5 up-faced arrows: cytosolic activation of JNK and p38 kinases leading to serine phosphorylation and subsequent inactivation of IRS-1; nuclear activation of NF-k $\beta$ and AP- 1 leading to enhance expression of IL-6, SOCS-3 and PTB-1B which in turn lead to attenuated activity of IRS-1, Akt, ERK 1/2 and dephosphorylation of insulin receptor followed by development of insulin resistance.

bolic actions. Consequently, we concluded that resistin/TLR4 signaling pathway seems to have a crucial role in the overall insulin-resistance and inflammation onset (8). Targeting this signaling pathway may constitute a significant breakthrough to overcome insulin resistance and inflammation, and related metabolic dysfunctions.

\section{Comparative effects of resistin in mice and humans}

Accumulating evidence indicates that changes in adipose-secreted factors in obesity, including release of inflammatory cytokines, dramatically affect insulin sensitivity (1, 5, 9-12). Among these adipokines, resistin is described as a potential factor in obesity-mediated insulin resistance and T2DM. Resistin is a cysteine-rich $12.5 \mathrm{kD}$ polypeptide secreted by adipose tissue in rodents and by macrophages (mainly) in humans (10, 13), promoting inflammation and insulin resistance (14-17). Circulating resistin is increased in obese insulin-resistant rodents $(12,13)$ and humans (13) and fasting decreases resistin mRNA expression $(12,18)$. Peripheral administration or transgenic overexpression of resistin in rodents impairs insulin ac- 
tion in insulin-sensitive tissues (19-21). Conversely, deletion of the resistin gene or infusing of resistin antibodies or antisense oligonucleotides restored insulin responsiveness (12, 22-24). More recently, it has been shown that resistin is expressed in the hypothalamus (25) and activates specific hypothalamic neurons (26). Central resistin also modulates glucose homeostasis, lipid metabolism, and food intake and impairs liver insulin sensitivity (27-30). Resistin also regulates the synthesis and secretion of key proinflammatory cytokines such as tumor necrosis factor-alpha, interleukin (IL)-6, and IL-12 in macrophages via a nuclear factor-kB-dependent pathway promoting insulin resistance (11, $12,31,32)$. However, whether the results obtained in mice are applicable to humans is still puzzling and controversial. Though some earlier publications questioned the link between resistin and insulin resistance in humans [see references 43-48 in (6)] our recent screening of the most recent 300 papers in PubMed under the term of resistin revealed 20 reports in which such an indirect link, evidenced by resistin levels in serum or tissues and various human pathologies such as adiposity, lung injury, metabolic syndrome, T2DM, gestational DM, diabetes-induced periodontitis, cardiovascular disease (CVD), non-alcoholic fatty liver disease (NFLD) and cancer was demonstrated (33-52). This issue was also widely addressed in the two most recent reviews. Abate et al (7) conclude that since inflammation plays a key role in the pathogenesis of T2DM (53) and resistin could be implicated in the development of T2DM, via induction of inflammation, adiposity or insulin resistance as shown in (54-56). In T2DM, macrophages, containing the highest levels of resistin gene expression $(57,58)$ that infiltrate the stroma of the adipose tissue and/or the vascular endothelium can locally produce and secrete resistin in addition to IL- $1 \beta$, TNF- $\alpha$, and IL-6, which may enhance the inflammatory load inducing insulin resistance and vascular dysfunction (58). Though macrophage infiltration into adipose tissue is a major feature of obesity, and macrophages are the main sources of resistin production, yet little is known about the differences in effects between serum and tissue resistin levels. Higher resistin levels have also been associated with T2DM complications, including renal dysfunction, atherosclerosis, gout, CVD, hypertension and peripheral neuropathy as shown in references 89-96 in Abate et al (7). Similar summary was reached by Park and Ahima in their recent review (6) who concluded: "Resistin was initially described as a link between obesity and insulin resistance in rodents. In rodents, resistin is almost exclusively expressed in white adipocytes, whereas human resistin is predominantly expressed in macrophages. The phenotypes of humanized resistin transgenic mice (59) suggest similar roles of murine and human resistin in insulin resistance. Studies in humanized resistin transgenic mice and epidemiolog- ical data also suggest that human resistin is a potential mediator between inflammation, and insulin resistance and atherosclerosis. Insights into the pathophysiological role of resistin will facilitate the development of novel diagnostic and treatment tools for diabetes, inflammation and CVDs".

\section{Putative link between insulin resistance and resistin polymorphism in humans}

Epidemiological studies conducted mainly in Japan linked resistin with insulin resistance and T2DM in humans. Polymorphism in the promoter of human resistin gene was positively associated with increased resistin levels in circulation (60). Particularly the $-420 \mathrm{C}>\mathrm{G}(\mathrm{G} / \mathrm{G})$ genotype at was associated with susceptibility to T2DM and also was correlated with monocyte resistin expression and with increased serum resistin levels $(61,62)$. Furthermore analysis of over 2000 Japanese subjects showed that plasma resistin was associated with SNP -420 and also correlated with insulin resistance (63). Similar results reported in a prospective study in China (64) and Egypt (65) but not in Korea (66) where the G/G (-420) genotype was associated with increased resistin levels but not with T2DM. In contrast, other studies were less conclusive: an Italian study showed that the presence of $-420 \mathrm{C} / \mathrm{G}$ SNP is associated with increased obesity and metabolic syndrome but not with resistin levels (67), in Caucasian nondiabetic subjects in North America resistin levels associated with $\mathrm{G} / \mathrm{G}(-420)$ genotype but not with insulin resistance (68), wheras in another study no such association was detected (69). So far the origin of those discrepancies remains not explained and requires further investigations.

\section{Interaction of resistin with TLR4 and other putative receptors}

The understanding the biological function of human resistin has been so far hampered by lack of information about its corresponding receptor and signaling mechanisms. In four recent reports several proteins have been suggested as potential receptors for resistin: a TLR4 (70), an isoform of decorin (71), mouse receptor tyrosine kinase-like orphan receptor 1 (ROR1) (72) and most recently adenylyl cyclase-associated protein 1 (CAP1) (73). It was reported that the latter directly binds to human resistin and elicits inflammatory effects in cultured human monocytes and in white adipose tissue (WAT) in humanized resistin mice in vivo. In contrast both decorin and ROR1 are only putative receptors for murine resistin, and none of these have been shown to mediate the inflammatory effects of resistin in humans. We have demonstrated that at the neuronal level in vivo in rats that TLR4 interacts with recombinant human resistin produced in our lab and its TLR4-mediated signaling in the hypothalamus 
lead to the activation of Jun NH2-terminal kinase (JNK) and p38 mitogen activated protein kinase (MAPK) signaling pathways by the recruitment of the adaptor proteins myeloid differentiating factor 88 (MyD88) and Toll/interleukin-1 receptor domain containing adaptor protein (TIRAP), promoting overall inflammation and enhancing insulin resistance (8). We have also shown that in SH-SY5Y human neuronal cells siRNA-mediated TLR4 knockdown impairs both resistin-induced inflammatory response and insulin resistance (8). Moreover, recent studies from other labs have provided evidence for the contribution of TLR4 in the pathogenesis of obesity and insulin resistance. Saturated fatty acids activate both hypothalamic and peripheral TLR4 signaling, leading to proinflammatory cytokine production and endoplasmic reticulum stress. Conversely, TLR4 lossof-function prevents saturated fatty acid-induced inflammation and insulin resistance (74-77). Resistin and TLR4 have been linked to a proinflammatory process in a human epithelial cell line in which resistin competes with lipopolysaccharide (LPS) for binding to TLR4 (70). In SH-SH5Y human neuronal cells we demonstrated that adiponectin exerts an insulin sensitizing effect by improving insulin signaling through recovering of IR expression and marked reduction of JNK and IRS-1 phosphorylations. Overexposure of SH-SY5Y cells to resistin induced the downregulation of APPL-1 and adiponectin receptors leading to the impairment of adiponectin signaling and knock down of TLR4 completely abrogated resistin effects on adiponectin signaling. This effect was also verified in vivo where 14 days ICV chronic resistin infusion of Wistar rats led to significant down-regulation of hypothalamic APPLL-1 (78). In addition, in rheumatoid arthritis disease, resistin has been shown to use the IGF-1R signaling pathway. In conclusion, though TLR4 seems to be the major resistin receptor, a puzzling situation in which resistin could potentially interact with different receptors depending upon cellular or in vivo model is still to be considerated.

\section{Development of resistin antagonist}

As formation of covalent resistin dimer C6 bisulfide (S-S) bond is crucial for its activity $(79,80)$ we speculated that mutation of C6A may convert resistin to an inactive monomer, or even to resistin receptor antagonist. The DNA encoding the ORF mutated at C6A was subcloned into pMon vector, and expressed as insoluble protein in E. coli (MON 105 strain) upon induction with nalidixic acid. Subsequently, insoluble inclusion bodies were prepared, solubilized in Tris-buffered guanidine in presence of reducing agent and refolded by 1:25 slow dilution into oxidizing solution containing urea, arginine and low concentration of cysteine at $4^{\circ} \mathrm{C}$. Then the monomeric fraction was isolated to purity by preparative size-exclusion chromatography. Once it's in vitro efficacy in abolishing resistin-dependent Akt and ERK $1 \frac{2}{2}$ phosphorylation in two types of cells was demonstrated it was termed resistin antagonist (RA) (81). Subsequently RA treatment of HFD-mice succeeded to reverse completely insulin resistance, to reduce the weight mainly due to reduction of visceral fat, to reduce expression of inflammatory cytokine IL6 and to attenuate HFD-induced neuro-inflammation and gliosis. In contrast, RA injections to lean mice fed chow diet did not affect the sensitivity to insulin, and even slightly (statistically borderline) increased their body weight (81). In view of those and others' results using C6S mutant in lean mice (13) it seems the RA may act differently in lean and HFD mice. The reason for this is not entirely clear but may be related to the higher levels of resistin in the later.

\section{Conclusions and future directions}

As many of the basic questions related to resistin role in insulin intolerance and metabolic syndrome remain unknown, development of potent competitive RAs may provide a potent research tool for the mechanistic study of resistin in non-genetically manipulated animals. Furthermore, such antagonist may be therapeutically employed to counteract resistin's pathogenic effects, such as those documented in metabolic syndrome, T2DM and neuroinflammation. Therefore, our main research objective is to develop a super-active resistin antagonist and to demonstrate its activity in various in vivo experiments. For such antagonist to be effective, its affinity to the resistin receptor (TLR4) must be considerably higher than that of the native resistin, resulting in effective competitive inhibition of resistin action in vivo. To achieve this aim it is needed to employ a high throughput technique, based on repetitive selection of randomly mutated RA molecule presented on a yeast surface display library and selected by high-affinity and avidity binding using repetitive rounds of cell sorting as was demonstrated in our preparation of super-active leptin antagonists (82). Furthermore to test the in vivo effectiveness of the RA and it high-affinity, putatively superactive RA there is a need to prepare its mono-pegylated analogue which will extend its in vivo half-life in circulation. Such development of the recombinant high affinity RA may provide new and significant research and therapeutic advantages: $(i)$ high throughput screening for structurally important binding motifs will extend our knowledge about resistin-TLR4 interactions, and (ii) the high affinity RA is expected to become an important new research tool in the field of metabolic syndrome biology, by allowing for the first time for potent and reversible inhibition of resistin. In vitro studies using the new molecules will enable the mechanistic study of downstream resistin effects on a variety of cells and tissues. In vivo, the superactive RA will enable the sys- 
tematic study by blocking of the effects of endogenous resistin in non-genetically manipulated animals. The high affinity binding of the superactive RA will enable to achieve effective peripheral and central resistin inhibition in tolerable antagonist doses, using non-genetically modified animal models. Also, (iii) such new knowledge will enable future utilization of RA to modulate pathologic situations in which local or systemic resistin activity has been convincingly shown to play pathological role such as cancer and CVD. Though the later aspects of resistin function are not covered in the present review, blocking resistin action maybe highly beneficial in several types of malignancy as summarized in recent reviews (83-86) and in ameliorating elevated serum low density lipoprotein and thereby atherosclerotic CVD in obese humans (87-89).

\section{References}

1. Kahn BB, Flier JS. Obesity and insulin resistance. J Clin Invest 2000; 106: 473-481. http://dx.doi.org/10.1172/jci10842

2. De Felice FG. Alzheimer's disease and insulin resistance: translating basic science into clinical applications. J Clin Invest 2013; 123: 531-539. http://dx.doi.org/10.1172/ jci64595

3. Wilcock DM, Griffin WS. Down's syndrome, neuroinflammation, and Alzheimer neuropathogenesis. J Neuroinflammation 2013; 10: 84. http://dx.doi. org/10.1186/1742-2094-10-84

4. Huang CC, Chung CM, Leu HB, Lin LY, Chiu CC, Hsu CY, et al. Diabetes mellitus and the risk of Alzheimer's disease: a nationwide population-based study. PLoS One 2014; 9: e87095. http://dx.doi.org/10.1371/journal.pone.0087095

5. Kahn SE, Hull RL, Utzschneider KM. Mechanisms linking obesity to insulin resistance and type 2 diabetes. Nature 2006; 444: 840-846. http://dx.doi.org/10.1038/nature05482

6. Park HK, Ahima RS. Resistin in rodents and humans. Diabetes Metab J 2013; 37: 404-414. http://dx.doi. org/10.4093/dmj.2013.37.6.404

7. Abate N, Sallam HS, Rizzo M, Nikolic D, Obradovic M, Bjelogrlic P, et al. Resistin: an inflammatory cytokine. Role in cardiovascular diseases, diabetes and the metabolic syndrome. Curr Pharm Des 2014; 20: 4961-4969.

8. Benomar Y, Gertler A, De Lacy P, Crepin D, Ould Hamouda $\mathrm{H}$, Riffault L, et al. Central resistin overexposure induces insulin resistance through Toll-like receptor 4. Diabetes 2013; 62: 102-114. http://dx.doi.org/10.2337/db12-0237

9. Steppan CM, Bailey ST, Bhat S, Brown EJ, Banerjee RR, Wright CM, et al. The hormone resistin links obesity to diabetes. Nature 2001; 409: 307-312. http://dx.doi. org/10.1038/35053000
10. Savage DB, Sewter CP, Klenk ES, Segal DG, Vidal-Puig A, Considine RV, et al. Resistin/ Fizz3 expression in relation to obesity and peroxisome proliferator-activated receptor-gamma action in humans. Diabetes 2001; 50: 2199-2202.

11. Wellen KE, Hotamisligil GS. Obesity-induced inflammatory changes in adipose tissue. J Clin Invest 2003; 112: 1785 1788. http://dx.doi.org/10.1172/jci20514

12. Olefsky JM, Glass CK. Macrophages, inflammation, and insulin resistance. Annu Rev Physiol 2010; 72: 219-246. http:// dx.doi.org/10.1146/annurev-physiol-021909-135846

13. Patel L, Buckels AC, Kinghorn IJ, Murdock PR, Holbrook JD, Plumpton C, et al. Resistin is expressed in human macrophages and directly regulated by PPAR gamma activators. Biochem Biophys Res Commun 2003; 300: 472-476.

14. Holcomb IN, Kabakoff RC, Chan B, Baker TW, Gurney A, Henzel W, et al. FIZZ1, a novel cysteine-rich secreted protein associated with pulmonary inflammation, defines a new gene family. EMBO J 2000; 19: 4046-4055. http://dx. doi.org/10.1093/emboj/19.15.4046

15. Reilly MP, Lehrke M, Wolfe ML, Rohatgi A, Lazar MA, Rader DJ. Resistin is an inflammatory marker of atherosclerosis in humans. Circulation 2005; 111: 932-939. http:// dx.doi.org/10.1161/01.cir.0000155620.10387.43

16. McTernan PG, Kusminski CM, Kumar S. Resistin. Curr Opin Lipidol 2006; 17: 170-175. http://dx.doi.org/10.1097/01. mol.0000217899.59820.9a

17. Mojiminiyi OA, Abdella NA. Associations of resistin with inflammation and insulin resistance in patients with type 2 diabetes mellitus. Scand J Clin Lab Invest 2007; 67: 215-225. http://dx.doi.org/10.1080/00365510601032532

18. Nogueiras R, Gualillo O, Caminos JE, Casanueva FF, Dieguez C. Regulation of resistin by gonadal, thyroid hormone, and nutritional status. Obes Res 2003; 11: 408-414. http://dx.doi.org/10.1038/oby.2003.55

19. Rajala MW, Obici S, Scherer PE, Rossetti L. Adiposederived resistin and gut-derived resistin-like molecule-beta selectively impair insulin action on glucose production. J Clin Invest 2003; 111: 225-230. http://dx.doi.org/10.1172/ jcil6521

20. Pravenec M, Kazdova L, Landa V, Zidek V, Mlejnek P, Jansa $\mathrm{P}$, et al. Transgenic and recombinant resistin impair skeletal muscle glucose metabolism in the spontaneously hypertensive rat. J Biol Chem 2003; 278: 45209-45215. http://dx.doi. org/10.1074/jbc.M304869200

21. Satoh H, Nguyen MT, Miles PD, Imamura T, Usui I, Olefsky JM. Adenovirus-mediated chronic "hyper-resistinemia" leads to in vivo insulin resistance in normal rats. J Clin Invest 2004; 114: 224-231. http://dx.doi.org/10.1172/jci20785 
22. Muse ED, Obici S, Bhanot S, Monia BP, McKay RA, Rajala MW, Scherer PE, Rossetti L. Role of resistin in diet-induced hepatic insulin resistance. J Clin Invest 2004; 114: 232-239. http://dx.doi.org/10.1172/jci21270

23. Banerjee RR, Rangwala SM, Shapiro JS, Rich AS, Rhoades B, Qi Y, Wang J, Rajala MW, Pocai A, Scherer PE, Steppan CM, Ahima RS, Obici S, Rossetti L, Lazar MA. Regulation of fasted blood glucose by resistin. Science 2004; 303: 11951198. http://dx.doi.org/10.1126/science.1092341

24. Qi Y, Nie Z, Lee YS, Singhal NS, Scherer PE, Lazar MA, Ahima RS. Loss of resistin improves glucose homeostasis in leptin deficiency. Diabetes 2006; 55: 3083-3090. http:// dx.doi.org/10.2337/db05-0615

25. Wilkinson M, Wilkinson D, Wiesner G, Morash B, Ur E. Hypothalamic resistin immunoreactivity is reduced by obesity in the mouse: co-localization with alpha-melanostimulating hormone. Neuroendocrinology 2005; 81: 19-30. http:// dx.doi.org/10.1159/000084871

26. Brunetti L, Orlando G, Recinella L, Michelotto B, Ferrante C, Vacca M. Resistin, but not adiponectin, inhibits dopamine and norepinephrine release in the hypothalamus. Eur J Pharmacol 2004; 493: 41-44. http://dx.doi.org/10.1016/j. ejphar.2004.04.020

27. Tovar S, Nogueiras R, Tung LY, Castaneda TR, Vazquez MJ, Morris A, et al. Central administration of resistin promotes short-term satiety in rats. Eur J Endocrinol 2005; 153: R1-5. http://dx.doi.org/10.1530/eje.1.01999

28. Muse ED, Lam TK, Scherer PE, Rossetti L. Hypothalamic resistin induces hepatic insulin resistance. J Clin Invest 2007; 117: 1670-1678. http://dx.doi.org/10.1172/jci30440

29. Vazquez MJ, Gonzalez CR, Varela L, Lage R, Tovar S, Sangiao-Alvarellos S, Williams LM, Vidal-Puig A, Nogueiras R, Lopez M, Dieguez C. Central resistin regulates hypothalamic and peripheral lipid metabolism in a nutritional-dependent fashion. Endocrinology 2008; 149: 45344543. http://dx.doi.org/10.1210/en.2007-1708

30. Singhal NS, Lazar MA, Ahima RS. Central resistin induces hepatic insulin resistance via neuropeptide Y. J Neurosci 2007; 27: 12924-12932. http://dx.doi.org/10.1523/jneurosci.2443-07.2007

31. Silswal N, Singh AK, Aruna B, Mukhopadhyay S, Ghosh S, Ehtesham NZ. Human resistin stimulates the pro-inflammatory cytokines TNF-alpha and IL-12 in macrophages by NF-kappaB-dependent pathway. Biochem Biophys Res Commun 2005; 334: 1092-1101. http://dx.doi.org/10.1016/j. bbrc.2005.06.202

32. Bokarewa M, Nagaev I, Dahlberg L, Smith U, Tarkowski A. Resistin, an adipokine with potent proinflammatory prop- erties. J Immunol 2005; 174: 5789-5795.

33. Kang Y, Park HJ, Kang MI, Lee HS, Lee SW, Lee SK, Park YB. Adipokines, inflammation, insulin resistance, and carotid atherosclerosis in patients with rheumatoid arthritis. Arthritis Res Ther 2013; 15: R194. http://dx.doi.org/10.1186/ $\operatorname{ar} 4384$

34. Wenning P, Kreutz T, Schmidt A, Opitz D, Graf C, Voss $S$, et al. Endurance exercise alters cellular immune status and resistin concentrations in men suffering from non-insulin-dependent type 2 diabetes. Exp Clin Endocrinol Diabetes 2013; 121: 475-482. http://dx.doi. org/10.1055/s-0033-1343395

35. Boyraz M, Cekmez F, Karaoglu A, Cinaz P, Durak M, Bideci A. Serum adiponectin, leptin, resistin and RBP4 levels in obese and metabolic syndrome children with nonalcoholic fatty liver disease. Biomark Med 2013; 7: 737-745. http://dx. doi.org/10.2217/bmm.13.13

36. Yuan H, Weng C, Yang Y, Huang L, Xing X. Resistin, an adipokine, may affect the improvement of insulin sensitivity in the metabolic syndrome patient treated with metformin. Med Hypotheses 2013; 81: 969-971. http://dx.doi. org/10.1016/j.mehy.2013.08.014

37. Ebert T, Roth I, Richter J, Tonjes A, Kralisch S, Lossner U, et al. Different associations of adipokines in lean and healthy adults. Horm Metab Res 2014; 46: 41-47. http://dx.doi. org/10.1055/s-0033-1353198

38. Dalamaga M. Resistin as a biomarker linking obesity and inflammation to cancer: potential clinical perspectives. Biomark Med 2014; 8: 107-118. http://dx.doi.org/10.2217/ bmm.13.99

39. Cabrera de Leon A, Almeida Gonzalez D, Gonzalez Hernandez A, Juan Aleman Sanchez J, Brito Diaz B, Dominguez Coello $S$, et al. The association of resistin with coronary disease in the general population. J Atheroscler Thromb 2014; 21: 273-281.

40. Habib SS, K AAR, Al Dokhi L. Assessment of adipokines relationships with cardiovascular risk markers in relation to body indices in normoglycemic males. Pak J Med Sci 2013; 29: 21-26. http://dx.doi.org/10.12669/pjms.291.2913

41. Nieva-Vazquez A, Perez-Fuentes R, Torres-Rasgado E, Lopez-Lopez JG, Romero JR. Serum resistin levels are associated with adiposity and insulin sensitivity in obese Hispanic subjects. Metab Syndr Relat Disord 2014; 12: 143148. http://dx.doi.org/10.1089/met.2013.0118

42. Sinan UY, Canbolat IP, Baydar O, Oktay V, Imre G, Kocas $\mathrm{C}$, et al. Relationship between increased serum resistin level and severity of coronary artery disease. Angiology 2014; 65: 239-242. http://dx.doi.org/10.1177/0003319713502718 
43. Rajkovic N, Zamaklar M, Lalic K, Jotic A, Lukic L, Milicic $\mathrm{T}$, et al. Relationship between obesity, adipocytokines and inflammatory markers in type 2 diabetes: relevance for cardiovascular risk prevention. Int J Environ Res Public Health 2014; 11: 4049-4065. http://dx.doi.org/10.3390/ ijerph110404049

44. Karatas A, Tuncay Isikkent N, Ozlu T, Demirin H. Relationship of maternal serum resistin and visfatin levels with gestational diabetes mellitus. Gynecol Endocrinol 2014; 30: 355-358. http://dx.doi.org/10.3109/09513590.2014.8876 70

45. Cruz-Dominguez MP, Cortes DH, Zarate A, Tapia-Gonzalez Mde L, Alvarez-Acosta S, Damasio L, et al. Relationship of ghrelin, acid uric and proinflammatory adipocytokines in different degrees of obesity or diabetes. Int J Clin Exp Med 2014; 7: 1435-1441.

46. Ho TP, Zhao X, Courville AB, Linderman JD, Smith S, Sebring N, et al. Effects of a 12-month moderate weight loss intervention on insulin sensitivity and inflammation status in nondiabetic overweight and obese subjects. Horm Metab Res 2014: http://dx.doi.org/10.1055/s-0034-1382011

47. Rachwalik M, Zysko D, Diakowska D, Kustrzycki W. Increased content of resistin in epicardial adipose tissue of patients with advanced coronary atherosclerosis and history of myocardial infarction. Thorac Cardiovasc Surg 2014: http://dx.doi.org/10.1055/s-0034-1376403

48. Jiang S, Park DW, Tadie JM, Gregoire M, Deshane J, Pittet JF, et al. Human resistin promotes neutrophil proinflammatory activation and neutrophil extracellular trap formation and increases severity of acute lung injury. J Immunol 2014; 192: 4795-4803. http://dx.doi.org/10.4049/jimmunol.1302764

49. Akagun T, Caliskan Y, Yazici H, Ozkok A, Telci A, Turkmen $A$, et al. Elevated resistin levels are associated with inflammation in hemodialysis patients with failed renal allografts. Int J Artif Organs 2014; 37: 358-363. http://dx.doi. org/10.5301/ijao.5000319

50. Chedraui P, Perez-Lopez FR, Escobar GS, Palla G, MonttGuevara M, Cecchi E, et al. Circulating leptin, resistin, adiponectin, visfatin, adipsin and ghrelin levels and insulin resistance in postmenopausal women with and without the metabolic syndrome. Maturitas 2014; 79: 86-90. http://dx. doi.org/10.1016/j.maturitas.2014.06.008

51. Devanoorkar A, Kathariya R, Guttiganur N, Gopalakrishnan D, Bagchi P. Resistin: a potential biomarker for periodontitis influenced diabetes mellitus and diabetes induced periodontitis. Dis Markers 2014; 2014: 930206. http://dx.doi. org/10.1155/2014/930206
52. Cabrera de Leon A, Almeida Gonzalez D, Gonzalez Hernandez A, Dominguez Coello S, Marrugat J, Juan Aleman Sanchez J, et al. Relationships between serum resistin and fat intake, serum lipid concentrations and adiposity in the general population. J Atheroscler Thromb 2014; 21: 454-462.

53. Yin J, Gao H, Yang J, Xu L, Li M. Measurement of salivary resistin level in patients with type 2 diabetes. Int J Endocrinol 2012; 2012: 359724. http://dx.doi.org/10.1155/2012/359724

54. Weisberg SP, McCann D, Desai M, Rosenbaum M, Leibel RL, Ferrante AW, Jr. Obesity is associated with macrophage accumulation in adipose tissue. J Clin Invest 2003; 112: 1796-1808. http://dx.doi.org/10.1172/jci19246

55. Chen BH, Song Y, Ding EL, Roberts CK, Manson JE, Rifai N, et al. Circulating levels of resistin and risk of type 2 diabetes in men and women: results from two prospective cohorts. Diabetes Care 2009; 32: 329-334. http://dx.doi.org/10.2337/ dc08-1625

56. Gharibeh MY, Al Tawallbeh GM, Abboud MM, Radaideh A, Alhader AA, Khabour OF. Correlation of plasma resistin with obesity and insulin resistance in type 2 diabetic patients. Diabetes Metab 2010; 36: 443-449. http://dx.doi. org/10.1016/j.diabet.2010.05.003

57. Curat CA, Wegner V, Sengenes C, Miranville A, Tonus C, Busse R, Bouloumie A. Macrophages in human visceral adipose tissue: increased accumulation in obesity and a source of resistin and visfatin. Diabetologia 2006; 49: 744-747. http://dx.doi.org/10.1007/s00125-006-0173-z

58. Tsiotra PC, Tsigos C, Anastasiou E, Yfanti E, Boutati E, Souvatzoglou E, et al. Peripheral mononuclear cell resistin mRNA expression is increased in type 2 diabetic women. Mediators Inflamm 2008; 2008: 892864. http://dx.doi. org/10.1155/2008/892864

59. Qatanani M, Szwergold NR, Greaves DR, Ahima RS, Lazar MA. Macrophage-derived human resistin exacerbates adipose tissue inflammation and insulin resistance in mice. $J$ Clin Invest 2009; 119: 531-539. http://dx.doi.org/10.1172/ jci37273

60. Azuma K, Oguchi S, Matsubara Y, Mamizuka T, Murata M, Kikuchi $\mathrm{H}$, et al. Novel resistin promoter polymorphisms: association with serum resistin level in Japanese obese individuals. Horm Metab Res 2004; 36: 564-570. http://dx.doi. org/10.1055/s-2004-825762

61. Osawa H, Yamada K, Onuma H, Murakami A, Ochi M, Kawata $\mathrm{H}$, et al. The $\mathrm{G} / \mathrm{G}$ genotype of a resistin single-nucleotide polymorphism at -420 increases type 2 diabetes mellitus susceptibility by inducing promoter activity through specific binding of Sp1/3. Am J Hum Genet 2004; 75: 678686. http://dx.doi.org/10.1086/424761 
62. Osawa H, Onuma H, Ochi M, Murakami A, Yamauchi J, Takasuka T, et al. Resistin SNP-420 determines its monocyte mRNA and serum levels inducing type 2 diabetes. Biochem Biophys Res Commun 2005; 335: 596-602. http:// dx.doi.org/10.1016/j.bbrc.2005.07.122

63. Osawa H, Tabara Y, Kawamoto R, Ohashi J, Ochi M, Onuma $\mathrm{H}$, et al. Plasma resistin, associated with single nucleotide polymorphism -420 , is correlated with insulin resistance, lower HDL cholesterol, and high-sensitivity C-reactive protein in the Japanese general population. Diabetes Care 2007; 30: 1501-1506. http://dx.doi.org/10.2337/dc06-1936

64. Xu JY, Sham PC, Xu A, Tso AW, Wat NM, Cheng KY, et al. Resistin gene polymorphisms and progression of glycaemia in southern Chinese: a 5-year prospective study. Clin Endocrinol (Oxf) 2007; 66: 211-217. http://dx.doi. org/10.1111/j.1365-2265.2006.02710.x

65. El-Shal AS, Pasha HF, Rashad NM. Association of resistin gene polymorphisms with insulin resistance in Egyptian obese patients. Gene 2013; 515: 233-238. http://dx.doi. org/10.1016/j.gene.2012.09.136

66. Cho YM, Youn BS, Chung SS, Kim KW, Lee HK, Yu KY, et al. Common genetic polymorphisms in the promoter of resistin gene are major determinants of plasma resistin concentrations in humans. Diabetologia 2004; 47: 559-565. http://dx.doi.org/10.1007/s00125-003-1319-x

67. Norata GD, Ongari M, Garlaschelli K, Tibolla G, Grigore L, Raselli S, et al. Effect of the $-420 \mathrm{C} / \mathrm{G}$ variant of the resistin gene promoter on metabolic syndrome, obesity, myocardial infarction and kidney dysfunction. J Intern Med 2007; 262: 104-112. http://dx.doi.org/10.1111/j.13652796.2007.01787.x

68. Qasim AN, Metkus TS, Tadesse M, Lehrke M, Restine S, Wolfe ML, et al. Resistin gene variation is associated with systemic inflammation but not plasma adipokine levels, metabolic syndrome or coronary atherosclerosis in nondiabetic Caucasians. Clin Endocrinol (Oxf) 2009; 70: 698705. http://dx.doi.org/10.1111/j.1365-2265.2008.03375.x

69. Hivert MF, Manning AK, McAteer JB, Dupuis J, Fox CS, Cupples LA, et al. Association of variants in RETN with plasma resistin levels and diabetes-related traits in the Framingham Offspring Study. Diabetes 2009; 58: 750-756. http://dx.doi.org/10.2337/db08-1339

70. Tarkowski A, Bjersing J, Shestakov A, Bokarewa MI. Resistin competes with lipopolysaccharide for binding to toll-like receptor 4. J Cell Mol Med 2010; 14: 1419-1431. http://dx.doi.org/10.1111/j.1582-4934.2009.00899.x

71. Daquinag AC, Zhang Y, Amaya-Manzanares F, Simmons PJ, Kolonin MG. An isoform of decorin is a resistin re- ceptor on the surface of adipose progenitor cells. Cell Stem Cell 2011; 9: 74-86. http://dx.doi.org/10.1016/j. stem.2011.05.017

72. Sanchez-Solana B, Laborda J, Baladron V. Mouse resistin modulates adipogenesis and glucose uptake in 3T3-L1 preadipocytes through the ROR1 receptor. Mol Endocrinol 2012; 26: 110-127. http://dx.doi.org/10.1210/me.20111027

73. Lee S, Lee HC, Kwon YW, Lee SE, Cho Y, Kim J, et al. Adenylyl cyclase-associated protein 1 is a receptor for human resistin and mediates inflammatory actions of human monocytes. Cell Metab 2014; 19: 484-497. http://dx.doi. org/10.1016/j.cmet.2014.01.013

74. Tsukumo DM, Carvalho-Filho MA, Carvalheira JB, Prada PO, Hirabara SM, Schenka AA, et al. Loss-of-function mutation in Toll-like receptor 4 prevents diet-induced obesity and insulin resistance. Diabetes 2007; 56: 1986-1998. http://dx.doi.org/10.2337/db06-1595

75. Shi H, Kokoeva MV, Inouye K, Tzameli I, Yin H, Flier JS. TLR4 links innate immunity and fatty acid-induced insulin resistance. J Clin Invest 2006; 116: 3015-3025. http:// dx.doi.org/10.1172/jci28898

76. Milanski M, Degasperi G, Coope A, Morari J, Denis R, Cintra DE, et al. Saturated fatty acids produce an inflammatory response predominantly through the activation of TLR4 signaling in hypothalamus: implications for the pathogenesis of obesity. J Neurosci 2009; 29: 359-370. http://dx.doi.org/10.1523/jneurosci.2760-08.2009

77. Saberi M, Woods NB, de Luca C, Schenk S, Lu JC, Bandyopadhyay G, et al. Hematopoietic cell-specific deletion of toll-like receptor 4 ameliorates hepatic and adipose tissue insulin resistance in high-fat-fed mice. Cell Metab 2009; 10: 419-429. http://dx.doi.org/10.1016/j. cmet.2009.09.006

78. Benomar Y, Gertler, A., Taouis, M. Resistin induces insulin resistance through Toll-like receptor 4 in SH-SY5Y human neuronal cells. American Endocrine Society Meeting: SUN-1053 (abstract). 2014:

79. Banerjee RR, Lazar MA. Dimerization of resistin and resistin-like molecules is determined by a single cysteine. J Biol Chem 2001; 276: 25970-25973. http://dx.doi. org/10.1074/jbc.M103109200

80. Graveleau C, Zaha VG, Mohajer A, Banerjee RR, DudleyRucker N, Steppan CM, et al. Mouse and human resistins impair glucose transport in primary mouse cardiomyocytes, and oligomerization is required for this biological action. J Biol Chem 2005; 280: 31679-31685. http://dx.doi. org/10.1074/jbc.M504008200 
81. Benomar Y, Solomon G, Ould-Hamouda H, Amine H, Othmane A, Gertler A, et al. Novel human resistin antagonist (monomeric C6A mutant) reduced body weight gain and restored insulin responsiveness in mice fed high fat diet [abstract]. American Endocrine Society Meeting 2014: SUN-1051.

82. Shpilman M, Niv-Spector L, Katz M, Varol C, Solomon G, Ayalon-Soffer M, et al. Development and characterization of high affinity leptins and leptin antagonists. J Biol Chem 2011; 286: 4429-4442. http://dx.doi.org/10.1074/jbc. M110.196402

83. Codoner-Franch P, Alonso-Iglesias E. Resistin: Insulin resistance to malignancy. Clin Chim Acta 2014; 438C: 46-54. http://dx.doi.org/10.1016/j.cca.2014.07.043

84. Joshi RK, Kim WJ, Lee SA. Association between obesity-related adipokines and colorectal cancer: a case-control study and meta-analysis. World J Gastroenterol 2014; 20: 79417949. http://dx.doi.org/10.3748/wjg.v20.i24.7941

85. Joshi RK, Lee SA. Obesity related adipokines and colorectal cancer: a review and meta-analysis. Asian Pac J Cancer Prev 2014; 15: 397-405.
86. Hsieh YY, Shen CH, Huang WS, Chin CC, Kuo YH, Hsieh $\mathrm{MC}$, et al. Resistin-induced stromal cell-derived factor-1 expression through Toll-like receptor 4 and activation of p38 MAPK/ NFkappaB signaling pathway in gastric cancer cells. J Biomed Sci 2014; 21: 59. http://dx.doi.org/10.1186/14230127-21-59

87. Melone M, Wilsie L, Palyha O, Strack A, Rashid S. Discovery of a new role of human resistin in hepatocyte low-density lipoprotein receptor suppression mediated in part by proprotein convertase subtilisin/kexin type 9. J Am Coll Cardiol 2012; 59: 1697-1705. http://dx.doi.org/10.1016/j. jacc.2011.11.064

88. Rashid S. What do high blood resistin levels mean for patients on statin therapy? Expert Rev Cardiovasc Ther 2013; 11: 255-257. http://dx.doi.org/10.1586/erc.12.176

89. Rashid S, Kastelein JJ. PCSK9 and resistin at the crossroads of the atherogenic dyslipidemia. Expert Rev Cardiovasc Ther 2013; 11: 1567-1577. http://dx.doi.org/10.1586/14779072.2 013.839204 